\title{
HOW QUALITATIVE ELEMENTS OF RELATIONAL EXCHANGES INFLUENCE AN IMPLEMENTATION OF PURCHASING MARKETING STRATEGIES - A CASE OF SERVICE COMPANIES IN SLOVENIA
}

\begin{abstract}
The author examines a relationship between the qualitative elements of relational exchanges and the implementation of relationship marketing strategies vs. transactional marketing strategies from the buyer's perspective in business-to-business exchanges. Therefore, four groups of qualitative relational exchange' factors have been determined: attractiveness of supplier, attractiveness of total purchasing market for the buyer, competitive position of the buyer on the purchasing market, and the bargaining orientation of the buyer toward its strategic supplier. Drawing on emerging perspectives on service companies with more than 200 employees in Slovenia and their relationship with strategic suppliers, the author proposes that a buyer's perception of qualitative elements of relational exchanges influences employment of particular marketing strategies towards its strategic supplier. Results of empirical study show some correlation between the groups of variables investigated. The influence of measured factors on the implementation of particular group of marketing strategies exists, although the strongest impact is prevailed especially by factors, which are characteristic for short-term relationships. Hence the surveyed companies are oriented much more toward achieving short-term efficiency instead of long-term effectiveness. This research makes a contribution to the strategy literature and to the practitioners, and has important implications for purchasing managers by offering guidelines for mixing the various aspects of partnering according to their objectives and strategies in order to improve the level of their relational approach to their strategic suppliers.
\end{abstract}

Key words: qualitative elements of relational exchange, transactional marketing, relationship marketing, purchasing marketing strategies.

JEL Classification: M310

\section{INTRODUCTION AND THEORETICAL BACKGROUND}

\subsection{INTRODUCTION}

Many researchers and managers support the thesis that one of the key goals of marketing is to build and sustain strong long-term relationships (Claycomb, Frankwick, 2010; Palmatier, Scheer, Evans, Arnold, 2008; De Wulf, Odekerken-Schroeder, and Iacobucci, 2001; Gummesson, 1995; Bagozzi, 1995; Groenroos, 1994; McKenna, 1991; Dwyer, Schurr, Oh, 1987). Therefore, the "new" paradigm of marketing in the $21^{\text {st }}$ century is based on longterm interactive bonds among market players. Hence, a deep insight into the characteristics of B2B relational exchange from the buyer's perspective is an important starting point to investigate a development of relationship marketing concept. It has its proponents not only in the marketing academia but in industry as well and has had a major impact upon the

\footnotetext{
${ }^{1}$ Matjaz Irsic, Ph.D., Assistant Professor, Marketing Department. Faculty of Economics and Business, University of Maribor, Slovenia. E-mail: matjaz.irsic@uni-mb.si.
} 
marketing discipline, triggering a paradigm shift away from transaction-based marketing toward a relationship focus.

While transactional exchange bases on the economic exchange among the participants (i.e. the participants try to maximize the benefit of discrete transaction), relational exchange is accompanied by the economic as well the social exchange, including the factors as: mutual dependence, friendship, closeness, trust, risk, cooperation, opportunism etc. (Bunduchi, 2008, 610-611).

There are a lot of advantages caused by long-term buyer-supplier relationships: provide a firm fast access to new technologies or markets; the ability to provide a wider range of goods and services; economies of scale in joint research and production; access to knowledge beyond a firm's boundaries; bridges to other firms; sharing of risks; and access to complementary skills (Johanson, Mattsson, 1987; Powell, 1987).

The relational exchange is very compounded construct and its elements influence the effectiveness of the relationship. Although there is a huge amount of authors who have analysed the topic mentioned above, there still exist a lot of open questions, especially about the role of specific relational elements in creating effective relationship between the partners.

At the same time, the relationships represent one of the greatest resources for developing sustainable competitive advantage (Claycomb, Frankwick, 2010, 252). On the other hand, the emergence process of coalitions and oppositions requests the adjustment of companies from the aspect of setting goals, strategies and tactical activities. The need for the external sources of purchasing diminishes the role of traditional concepts of the company on the purchasing market in order to determine the partners' negotiating strength. The efficient and effective creation of the purchasing marketing strategies toward important strategic suppliers in such circumstances requires a thorough knowledge of such relationships, necessary conditions for their creation, strengths and weaknesses of such the relationships, as well as their outputs (Shah, Swaminathan, 2008, 471-472).

On the base of the above mentioned problem, the purpose of this paper is to link the selected elements (qualitative elements) of relational exchanges with the implementation of particular purchasing marketing strategies in $\mathrm{B} 2 \mathrm{~B}$ context as well as to find out if there exist the correlation between selected elements of relational exchanges and the frequency of implementation of purchasing marketing strategies.

Further, we tried to find out do the selected elements of relational exchanges influence the "trade-off" decision of the companies to implement transactional or relational purchasing marketing strategies.

In addition to this fact, it is significant to emphasize the lack of research evidence about this problem in the service industry, although the size of the service sector is increasing in virtually all countries around the world (Lovelock, Wirtz, 2011, 27). Therefore, the service companies in Slovenia have offered the empirical context for the research in this paper.

\subsection{THE ELEMENTS OF BUYER'S B2B RELATIONAL EXCHANGES}

The review of the current literature about the characteristics of relational exchange uncovers the numerous of elements, which influence the effectiveness of the relationship. In our paper four qualitative elements of relational exchange have been chosen: attractiveness of a supplier, attractiveness of total purchasing market for a buyer, competitive position of a buyer on purchasing market, and bargaining orientation of a buyer.

First and second elements comprize the key strategic factors of purchasing environment of a buyer, while the third one comprizes the key strategic factors of competitive position of a buyer. Thus, we found the theoretical base for the selection of three of elements 
in »General electric« (GE) multifactor portfolio matrix, which represents a widely used managerial and methodological tool for strategic decision-making process in the companies (Lancaster, Reynolds, 1998, 139-140). Therefore, it represents meaningfull construct in the estimation of the relational exchange.

The first well-known dimension of GE matrix - »attractiveness of the market« (i.e. market opportunities and threats) we split into two sub-groups: attractiveness of a supplier and attractivenss of other elements of purchasing market for a buyer, in order to expose the supplier as an important market subject in the process of investigating the relational exchange chracteristics.

The third element - competitive position of a buyer on the purchasing market derived from the second dimension of GE matrix - »competitive position « (i.e. company's competences based on its strengths and weaknesses).

The fourth element of relational exchange investigated in the paper comprizes behavioural characteristics of the relational exchange. Therefore, Westbrook model of bargaining orientation of a buyer toward a supplier (Westbrook, 1996) has been chosen to clearly understand the process of disposing bargaining power among the participants in the relational exchange.

In the following text we have briefly described the main theoretical background of each above mentioned elements.

\section{a) Attractiveness of supplier and other dimensions of purchasing market of a buyer}

Evaluation of suppliers' attractiveness is usually compound from a number of different factors, through which the buyer's company judges supplier's capability to build and maintain long-term relational exchange, i.e. financial, economic, technological, cultural, and strategic factors of performance (Ellram, 1990; Lambe, Spekman and Hunt, 2002; Beckman, Haunschild and Phillips, 2004; Wuyts and Geyskens, 2005).

In addition to this general factors, mentioned above, it seems to be crucial to emphasize some specific or derivate factors: management' ability of supplier, strength and competences of employees in the company of supplier, supplier's cost structure, total quality system of implementation (for the products, systems, processes, technology, and philosophy), ability of supplier to adopt environmental changes, its financial stability, company of production and control mechanisms, development of electronic communication, supplier's strategies and activities, and supplier's potential for long-term cooperation (Monczka, Trent and Handfield, 2005, 215-222).

An extensive review of the literature on strategic alliances (relational exchange) in strategic management uncovered four key factors that have been shown to influence supplier's selection and subsequent relational exchange performance: trust, commitment, complementarity, and value or financial payoff (Shah and Swaminathan, 2008, 472; Hald, Cordon, Vollmann, 2009, 960-970).

Attractiveness of total purchasing market for the buyer corresponds with its opportunities and threats. The prevailing factors in this group of qualitative elements are as follows: the size of purchasing market (or availability of substitutes), its growth rate and structure, intensity of competition, technological, cultural, legal, political, economic and other relevant factors of macro-environment (Saunders, 1997, 55).

\section{b) Buyer's competitive position on the purchasing market}

Buyer's competitive position has derived from strategic analysis and prognosis of its internal (company) environment, i.e. analysis of its resources and competences. The result of 
such analyses has brought to the buyer the information of its "core" competitive advantages and disadvantages.

An explanation of competitive advantage bases on two prevailing theoretical concepts: "resource-based" concept and "relational-view" concept of the company.

Advocators of "resource-based" concept interpret a competitive position of the company as a result of such available resources and abilities which couldn't be imitated in a short time (i.e. company's image, market share, customer satisfaction, product quality, distribution efficiency, knowledge and specific competences of employees etc.). On the other side, the defenders of "relational-view" concept explain that company's competitive position has not derived from the internal (company's) environment, but it has based on "business-tobusiness" sources of competitive advantages, i.e. on transaction specific investments between a buyer and a supplier in the relational exchange (integrated knowledge of both partners, mutual and integrated effectiveness of performance, information systems among them, integrated marketing communication etc.) (Mesquita, Anand and Brush, 2008, 913).

\section{c) Bargaining orientation of a buyer toward a supplier}

Each relational exchange is closely associated with a specific "transaction climate" comprised from sentiments and behaviours, expectations, perceptions, feelings etc. of participants involved into such relationship. All these elements of transaction climate are linked with specific level of cooperation, opportunism, dependence, conflicts, risks, trust, orientation to reciprocity, satisfaction etc. (Westbrook, 1996; Palmer and Mayer, 1996; Bove and Johsnon, 2001; Walter, Muller, Helfert and Ritter, 2003; Duffy, 2008).

Relevant researchers of this topic state that the level of cooperative (and opportunistic) behaviour can be interpreted by four theoretical constructs: trust, commitment, relational norms, and methods of solving functional conflicts (Dwyer et al. 1987; Heide and John, 1992; Morgan and Hunt, 1994; Siguaw, Baker and Simpson, 1998; Duffy, 2008). Some level of cooperation among participants in relational exchange is a requisite for achieving them. But, the cooperation between a buyer and a supplier has been usually followed by their unilateral behaviour with risk coordination in which the participant estimates a willingness for cooperative behaviour of opposite participant (Westbrook, 1996; Batt and Purchase, 2004; Ritter, Wilkinson and Johnston, 2004; Johnson and Selnes, 2004; Palmatier, Scheer, Evans and Arnold, 2008).

Westbrook has defined four variables by which a participant's behaviour in relational exchange with risk coordination and bargaining orientation at the same time can be explained: risk orientation, orientation towards cooperation, power (dependence), and orientation towards reciprocity (Westbrook, 1996).

\subsection{PURCHASING MARKETING STRATEGIES}

Those companies which implement marketing orientation on the purchasing market will perform purchasing marketing strategies in order to attain comparative competitive advantages on the purchasing market. In the existing literature, authors deal with factors influencing the choice of purchasing marketing strategies in a similar way.

Baily, Farmer, Jessop and Jones mention the following factors influencing the choice of the purchasing strategy (Baily, Farmer, Jessop, Jones, 1994, 26-28): the position of purchasing in the purchasing chain, the number of favourable resources on the purchasing market, technological development on the purchasing and selling market, stability of purchasing and selling markets, the level of state intervention on the market and the ability of the organisation to manage a certain strategy on the purchasing market. 
In addition to market factors, Qualls and Puto also mention the important role of organisational factors, which have an influence on decisions and strategies on the purchasing market. Here, we have to distinguish between taking decisions in conditions of certainty (without risk) and conditions of uncertainty (small, medium or large risk) (Qualls, Puto, 1989, 180-182).

Anders sets the basis for a slightly different definition of purchasing strategies. As important factors influencing basic strategic orientation of the company, Anders mentions purchasing volume and market potential on the purchasing market. Purchasing volume indicates the importance of the purchasing object for the organisation and the relation between the importance of the purchasing object and the necessary scope (ABC - analysis), whereas the market potential shows the quantity of potential supply for a group of purchasing objects. Thus the definition of the purchasing marketing strategy will depend on the intensity of demand, which necessitates a selection of a suitable demand strategy (Anders, 1992, 24).

Koppelmann comes to similar conclusions by defining purchasing potential as an important restricting factor and a starting point for the formation of strategies in the context of purchasing marketing. Purchasing potential is a potential of the company which depends on its advantages and disadvantages. Since purchasing potential represents a restricting factor in purchasing, it indirectly affects the definition of purchasing marketing strategies (Koppelmann, 1993, 111-113). His model of purchasing strategies represents the fundament for empirical part of our research in this paper.

At the same time, it is significant to emphasize, that there is no vigorous research evidence in the literature about the characteristics of transactional and relational purchasing marketing strategies. 


\section{RESEARCH}

\subsection{THE DEVELOPMENT OF AN EMPIRICAL MODEL}

Our research was based on an empirical model, in which the most significant relationships and interdependencies between variables revealed are seen in figure 1 .

Figure 1: Empirical model of relations between qualitative elements of relational exchange (independent variables $X_{n}$ ) and purchasing marketing strategies with two aggregate groups of dependent variables $\left(Y_{a}\right.$ and $\left.Y_{b}\right)$.



As it has been seen from figure 1, qualitative elements of relational exchange in our empirical model have been defined by four groups of numerical independent variables (x): attractiveness of a supplier, attractiveness of total purchasing market for a buyer, competitive position of a buyer on purchasing market, and bargaining orientation of a buyer: $X=f\left({ }_{1}, x_{2}\right.$, $\left.\mathrm{X}_{3}, \mathrm{X}_{4}\right)$.

For each of four above mentioned groups of constructs we developed independent variables, which have been tested for convergent and discriminant validity and reliability of the measures.

Attractiveness of a supplier $\left(\mathrm{x}_{1}\right)$ has been evaluated by nine factors (independent numerical variables): supplier's capacity, location, supplier's financial status, technology, management, quality of products, delivery in due time, purchase price and supplier's ability to meet the market requirements.

Measurement of the attractiveness of total purchasing market for a buyer $\left(\mathrm{x}_{2}\right)$ based on the following seven factors that have been considered: the size of the purchasing market (or the availability of substitutes), the growth rate of the purchasing market, its structure (number of buyers and suppliers), stability of the demand, obstacles for entering the industry (entry barriers), obstacles for exiting the industry (exit barriers), and the possibility for a backward vertical integration.

With regard to the competitive position of a buyer on the purchasing market $\left(\mathrm{x}_{3}\right)$ eight factors were considered: purchasing potential, "switching" costs, the ratio between supply costs and total purchasing value, the growth rate of purchases, marketing communication 
performance, buyer's image assessment, information knowledge of a buyer, and price elasticity of demand.

Bargaining orientation of a buyer toward a supplier $\left(\mathrm{x}_{4}\right)$ has been investigated by two main independent variables, i.e. buyer's orientation toward risk and buyer's orientation toward cooperation.

For each of independent variables (factors) the weighted estimation has been measured. It was compounded by respondent's evaluation of a factor and the estimated level of significance of the factor for the respondent as follows:

Weighted estimation of a factor $=$ Respondent's evaluation of a factor $*$ Estimated level of significance of the factor for the respondent.

Both of estimations were measured on the 5-pt. numerical interval scale.

The construct of dependent variables has been composed by 25 selected purchasing marketing strategies based on relevant instruments of purchasing marketing mix: product (service) strategies, price' and terms of exchange' strategies, delivery and inventory strategies, strategies of sources of supply, strategies of processes between a buyer and a supplier, and purchasing marketing communication strategies. Such selection of strategies reveals individual marketing activities of the buyers on their purchasing market. The above mentioned model based on Koppelmann classification of the purchasing marketing strategies (Koppelmann, 1993).

Since, we have looked on "trade-off" between transactional and relational content of purchasing marketing strategies, we split the selected group of 25 strategies onto two subgroups: transactional purchasing marketing strategies $\left(\mathrm{Y}_{\mathrm{A}}\right.$, type $\left.\mathrm{A}\right)$ and relational purchasing marketing strategies ( $\mathrm{Y}_{\mathrm{B}}$, type $\left.\mathrm{B}\right)$. Transactional purchasing marketing strategies are prevailing in transactional exchanges, while relational purchasing marketing strategies are symptomatic for relational exchanges. For each of the selected strategy the frequency of its implementation has been measured in the buyers' companies on the 5-pt. numerical interval scale ranging from $1-\gg$ never implemented « to 5 - »always implemented «.

\subsection{RESEARCH METHODOLOGY}

\section{a) The validation of the constructs}

In the first phase some of the relevant items for the questionnaire were taken from the relevant literature (see 2.1).

In order to assure convergent validity and reliability of the measures, the dimensionality of six constructs created (attractiveness of a supplier, attractiveness of total purchasing market for a buyer, competitive position of a buyer on purchasing market, bargaining orientation of a buyer, transactional purchasing marketing strategies, and relational purchasing marketing strategies) was assessed in the second phase. Therefore, exploratory factor analysis (EFA) as well as confirmatory factor analysis (CFA) were used. Factor loadings (FL), component reliability (CR) and average variance extracted (AVE) measures for groups of independent variables are shown in table 1 and for groups of dependent variables are shown in table 2 . 


\section{Table 1:}

Constructs (with independent variables), standardized loadings (FL), CR, and AVE

\begin{tabular}{|c|c|c|c|c|}
\hline Constructs & Variables & FL & $\mathbf{C R}$ & AVE \\
\hline \multirow{9}{*}{$\begin{array}{l}\text { Attractiveness } \\
\text { of a supplier } \\
\left(\mathrm{x}_{1}\right)\end{array}$} & Supplier's capacity & 0,822 & \multirow[t]{9}{*}{0,74} & \multirow[t]{9}{*}{0,56} \\
\hline & Location & 0,745 & & \\
\hline & Supplier's financial status & 0,670 & & \\
\hline & Technology & 0,566 & & \\
\hline & Management of a supplier & 0,550 & & \\
\hline & Quality of products & 0,780 & & \\
\hline & Delivery in due time & 0,756 & & \\
\hline & Purchase price & 0,600 & & \\
\hline & $\begin{array}{l}\text { Supplier's ability to meet market } \\
\text { requirements }\end{array}$ & 0,645 & & \\
\hline \multirow{7}{*}{$\begin{array}{l}\text { Attractiveness } \\
\text { of total } \\
\text { purchasing } \\
\text { market for a } \\
\text { buyer }\left(\mathrm{x}_{2}\right)\end{array}$} & The size of a purchasing market & 0,786 & \multirow[t]{7}{*}{0,66} & \multirow[t]{7}{*}{0,54} \\
\hline & The growth rate of the purchasing market & 0,688 & & \\
\hline & Structure of a market & 0,661 & & \\
\hline & Stability of demand & 0,688 & & \\
\hline & Entry barriers & 0,890 & & \\
\hline & Exit barriers & 0,790 & & \\
\hline & Possibility for a backward vertical integration & 0,689 & & \\
\hline \multirow{8}{*}{$\begin{array}{l}\text { Competitive } \\
\text { position of a } \\
\text { buyer on the } \\
\text { purchasing } \\
\text { market }\left(x_{3}\right)\end{array}$} & Purchasing potential & 0,778 & \multirow[t]{8}{*}{0,76} & \multirow[t]{8}{*}{0,59} \\
\hline & "Switching" costs & 0,668 & & \\
\hline & $\begin{array}{l}\begin{array}{l}\text { Ratio between supply costs and total } \\
\text { purchasing value }\end{array} \\
\end{array}$ & 0,775 & & \\
\hline & Growth rate of purchases & 0,776 & & \\
\hline & Marketing communication performance & 0,624 & & \\
\hline & Buyer's image assessment & 0,689 & & \\
\hline & Information' knowledge of a buyer & 0,789 & & \\
\hline & Price elasticity of demand & 0,580 & & \\
\hline \multirow{2}{*}{$\begin{array}{l}\text { Bargaining } \\
\text { orientation }\left(\mathrm{x}_{4}\right)\end{array}$} & Buyer's orientation toward risk & 0,745 & \multirow[t]{2}{*}{0,88} & \multirow[t]{2}{*}{0,64} \\
\hline & Buyer's orientation toward cooperation & 0,810 & & \\
\hline
\end{tabular}


Table 2:

Constructs (with dependent variables), standardized loadings (FL), CR, and AVE

\begin{tabular}{|c|c|c|c|c|}
\hline Construct & Strategies & FL & $\mathbf{C R}$ & AVE \\
\hline \multirow{8}{*}{$\begin{array}{l}\text { Transactional } \\
\text { purchasing } \\
\text { marketing } \\
\text { strategies }\left(\mathrm{y}_{\mathrm{A}}\right)\end{array}$} & $\begin{array}{l}\text { The strategy of instantaneous purchases based } \\
\text { on classical buyer-supplier relationships }\end{array}$ & 0,768 & \multirow[t]{8}{*}{0,626} & \multirow[t]{8}{*}{0,759} \\
\hline & $\begin{array}{l}\text { The strategy of product standardization, with } \\
\text { an alternative: purchased products are made } \\
\text { according to your specifications or plan }\end{array}$ & 0,567 & & \\
\hline & The average market price strategy & 0,560 & & \\
\hline & $\begin{array}{l}\text { The higher-than-average market price } \\
\text { strategy }\end{array}$ & 0,589 & & \\
\hline & The occasional substantial order strategy & 0,575 & & \\
\hline & $\begin{array}{l}\text { We have two or more alternative sources for } \\
\text { occasionally purchasing the most important } \\
\text { strategic products }\end{array}$ & 0,640 & & \\
\hline & $\begin{array}{l}\text { The strategy of occasional communication } \\
\text { ("when necessary") }\end{array}$ & 0,674 & & \\
\hline & $\begin{array}{l}\text { The strategies aimed at the promotion of } \\
\text { purchasing from the existing (chosen) } \\
\text { suppliers in order to reach favourable } \\
\text { purchasing terms }\end{array}$ & 0,520 & & \\
\hline \multirow{11}{*}{$\begin{array}{l}\text { Relational } \\
\text { purchasing } \\
\text { marketing } \\
\text { strategies } \\
\left(\mathrm{y}_{\mathrm{B}}\right)\end{array}$} & $\begin{array}{l}\text { The strategy of cooperation with the supplier } \\
\text { in the development of a new product of the } \\
\text { company (the so-called "simultaneous } \\
\text { engineering") }\end{array}$ & 0,610 & \multirow[t]{11}{*}{0,679} & \multirow[t]{11}{*}{0,893} \\
\hline & $\begin{array}{l}\text { Cooperation with the supplier in activities } \\
\text { related to the product launch, modification of } \\
\text { an existing product or removing products } \\
\text { from the market }\end{array}$ & 0,624 & & \\
\hline & $\begin{array}{l}\text { The strategy "Poka-Yoke" within the total } \\
\text { quality management (TQM) }\end{array}$ & 0,670 & & \\
\hline & $\begin{array}{l}\text { The lowest purchasing price strategy with } \\
\text { regard to other potential supplier for a certain } \\
\text { product }\end{array}$ & 0,636 & & \\
\hline & $\begin{array}{l}\text { The "no stock" strategy (i.e. "just-in-time" } \\
\text { strategy) }\end{array}$ & 0,575 & & \\
\hline & The multiple small quantity orders strategy & 0,540 & & \\
\hline & $\begin{array}{l}\text { The most important strategic product is } \\
\text { purchased from one supplier only }\end{array}$ & 0,780 & & \\
\hline & $\begin{array}{l}\text { Together with the supplier we intensify } \\
\text { competition among suppliers }\end{array}$ & 0,891 & & \\
\hline & $\begin{array}{l}\text { The strategy of knowledge, information and } \\
\text { technology transfer ("know-how") }\end{array}$ & 0,630 & & \\
\hline & $\begin{array}{l}\text { The advertising strategy aimed at long-term } \\
\text { cooperation between the buyer and supplier }\end{array}$ & 0,714 & & \\
\hline & $\begin{array}{l}\text { Public relations strategy aimed at building a } \\
\text { positive image in the local and wider } \\
\text { environment }\end{array}$ & 0,520 & & \\
\hline
\end{tabular}




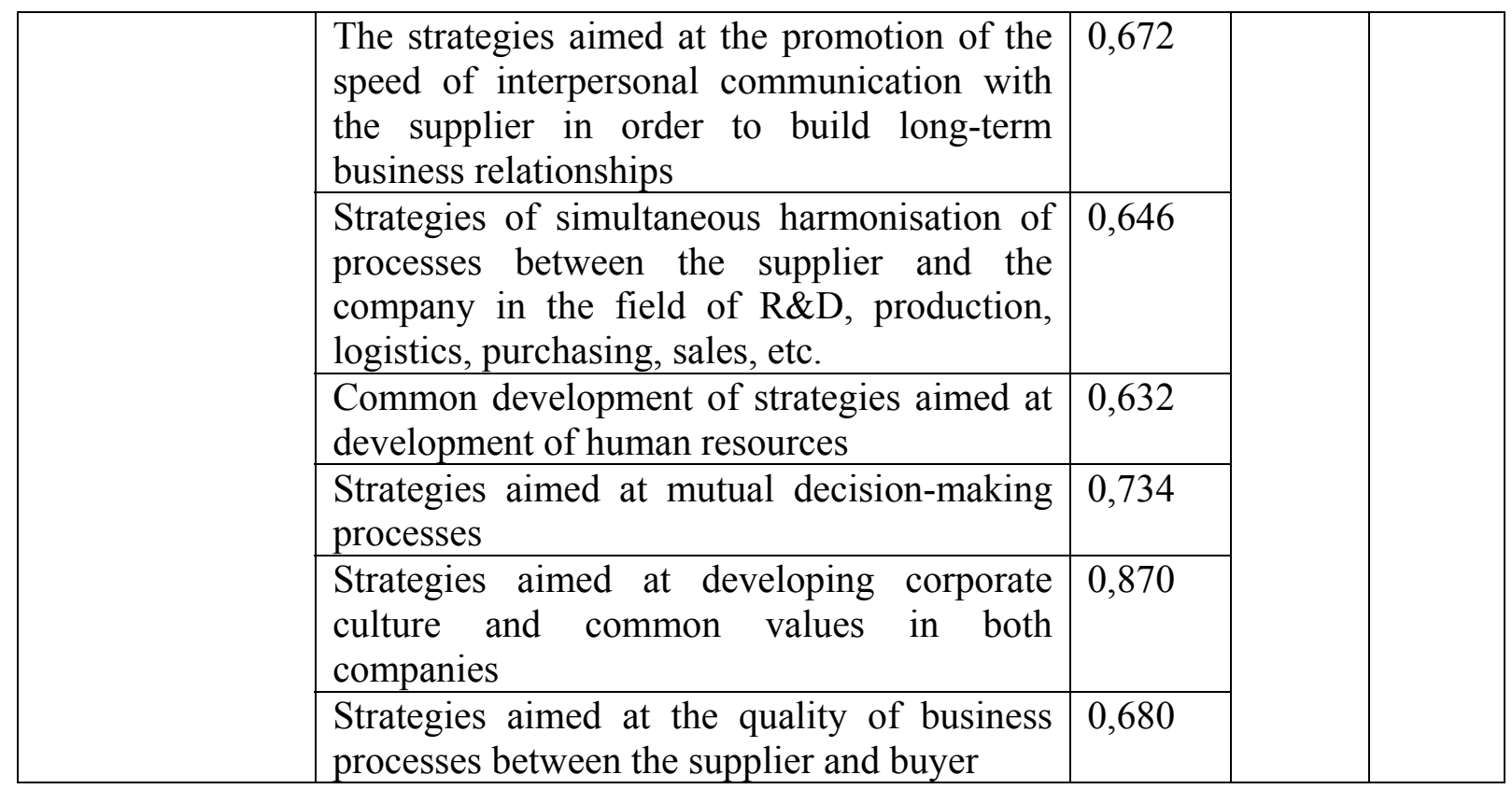

The reliability of the constructs was assessed with Cronbach $\alpha$ measurement. The constructs with independent variables represented ranges from 0,66 to 0,88 , while the constructs with dependent variables ranges from 0,626 to 0,679 , which met the standard of 0,60 as suggested by Nunnally (1978).

Evidence of convergent validity was determined by inspection of the average variance extracted (AVE) for each construct has shown that the value exceeds the lower limit of 0,50 for each construct.

\section{b) Sampling}

All service companies on B2B market with more than 200 employees in Slovenia were included into our research. The justification for the selection of these companies based in the fact that in larger companies (with regard to number of employees) the purchasing function is more complex and sophisticated as well as of greater influence in creating the company's performance. In every company, a single respondent was identified in the position of CEO or member of the Board of Directors responsible for marketing or purchasing. Key respondents were used, as senior managers have been shown to be generally reliable in their evaluations of company's activities and performance (e.g. Venkatraman, Ramanujan, 1986). A highly structured questionnaire was mailed to all of 141 companies in service industry with more than 200 employees in Slovenia (Dec. 31 ${ }^{\text {st }}, 2008$ ). In total, 90 usable questionnaires were received, representing a response rate of $63,8 \%$.

\section{c) Research objectives and hypotheses development}

There is a lack of empirical evidence in the recent literature about how the attractiveness of a supplier and the total purchasing market of a buyer, as well as its competitive position and bargaining orientation influence the performance of strategic activities of the buyer in the B2B context. At the same time, some up-to-date empirical models verified the correlation between selected marketing tactics in increasing the loyal behaviours of buyers (Mitrega, Katrichis, 2010) or investigated various aspects of the effectiveness of relationship-based strategies (DeWulf, Odekerken-Schroeder, Iacobucci, 
2001; Palmatier, Dant, Grewal, 2007). It is evidently that the implementation of purchasing marketing strategies of the buyers on their purchasing market in $\mathrm{B} 2 \mathrm{~B}$ relations contributes to the level of commitment of the buyer in the relationship between the buyer and the supplier as well as to the performance outcomes of the buyer. Empirical research also indicated that the performance of purchasing marketing strategies of the buyers on their B2B markets reveals buyer's overall relationship orientation (Palmatier, Scheer, Evans, Arnold, 2008, 185). Therefore, it is important to recognize, are the purchasing marketing strategies transactional oriented or relational oriented and to investigate, which elements of buyer's internal (competitive position) and external market environment (attractiveness of the supplier and other elements of purchasing market) contribute to the strategic decision of the buyers, i.e. which purchasing marketing strategy to formulate and implement.

Thus, the main research objective was to find out, which relevant factors in the selected four constructs of qualitative elements of the relational exchange influence a selection of particular purchasing marketing strategies and to establish, what are the characteristics of these strategies, i.e. do they belong to the transactional or relational group of strategies.

On the basis of the empirical model, which has been explained (see figure 1) and the main research objective, four pairs of research hypotheses have been proposed:

$\mathbf{H}_{1 \mathbf{a}}$ : There is a negative correlation between the weighted estimation of the majority of factors, with which the level of the attractiveness of a supplier has been measured, and the frequency of implementation of transactional purchasing marketing strategies.

$\mathbf{H}_{1 \mathbf{b}}$ : There is a positive correlation between the weighted estimation of the majority of factors, with which the level of the attractiveness of a supplier has been measured, and the frequency of implementation of relationship purchasing marketing strategies.

$\mathbf{H}_{2 \mathrm{a}}$ : There is a positive correlation between the weighted estimation of the majority of factors, with which the level of attractiveness of total purchasing market for a buyer has been measured, and the frequency of implementation of transactional purchasing marketing strategies.

$\mathbf{H}_{2 \mathbf{b}}$ : There is a negative correlation between the weighted estimation of the majority of factors, with which the level of attractiveness of total purchasing market for a buyer has been measured, and the frequency of implementation of relationship purchasing marketing strategies.

$\mathbf{H}_{3 \mathbf{a}}$ : There is a positive correlation between the weighted estimation of the majority of factors, with which the buyer's competitive position on the purchasing market has been measured, and the frequency of implementation of transactional purchasing marketing strategies.

$\mathbf{H}_{\mathbf{3} \mathbf{b}}$ : There is a negative correlation between the weighted estimation of the majority of factors, with which the buyer's competitive position on the purchasing market has been measured, and the frequency of implementation of relationship purchasing marketing strategies.

$\mathbf{H}_{4 \mathrm{a}}$ : There is a positive correlation between the weighted estimation of the majority of factors, with which the buyer's bargaining orientation toward a supplier has been measured, and the frequency of implementation of transactional purchasing marketing strategies.

$\mathbf{H}_{\mathbf{4}}$ : There is a negative correlation between the weighted estimation of the majority of factors, with which the buyer's bargaining orientation toward a supplier has been measured, and the frequency of implementation of relationship purchasing marketing strategies. 


\section{d) Methods of analysing data}

In order to analyse data collected in our research, the method of multiple discriminant analysis has used to derive the linear combination of independent variables that will discriminate best between the a priori defined groups of constructs as well as to determine which independent variables count most in explaining differences between the constructs with dependent variables.

Further, with the method of canonical correlation we revealed the correlation between the above mentioned linear combinations in order to maximize this correlation. Since the canonical correlation analysis is an appropriate statistical technique when we have two criterion variables (dependent variables) and multiple predictor variables (independent variables), we aggregated the frequencies of implementation of individual dependent variables (purchasing marketing strategies) into two aggregated means: $\mathrm{Y}_{\mathrm{A}}$ represents aggregate mean of the frequency of implementation of transactional purchasing marketing strategies and $Y_{B}$ represents the aggregate mean of relational purchasing marketing strategies.

The significance of the discriminant function was measured with statistical testing through Wilks' $\lambda$.

\subsection{RESEARCH RESULTS}

In order to test the research hypotheses with the statistical methods mentioned above, we tried to find out:

(1) What is the correlation between series of independent variables $x_{n}$ (i.e. individual qualitative factors of relational exchanges), and individual aggregate dependent variable $Y$ ?

We considered as statistically significant canonical correlation coefficients where $-0,5 \geq R \geq$ 0,5 .

(2) Are there some significant differences between the values of aggregate dependent variables $\left(\mathrm{Y}_{\mathrm{A}}\right.$ and $\left.\mathrm{Y}_{\mathrm{B}}\right)$, i.e. with regard to the frequency of implementation of purchasing marketing strategies of type $A$ and type $B$ from the point of view of individual set of independent variables (i.e. qualitative factors of relational exchange)?

(3) Which of the chosen independent variables add most towards the discrimination among both aggregate sets of dependent variables; standardized canonical coefficients of discriminant function have been taken as statistically significant, if they have been higher than 0,5 or lower than $-0,5$.

For each set of independent variables (x) we have considered the canonical discriminant function with the highest "eigenvalue" and the highest Chi-square test, which means that it makes it easier to discriminate between the sets of variables and, at the same time, the lowest Wilks' lambda.

a) Factors for evaluating the attractiveness of a supplier

Table 3: Discriminant analysis for a series of independent variables $x_{1}$

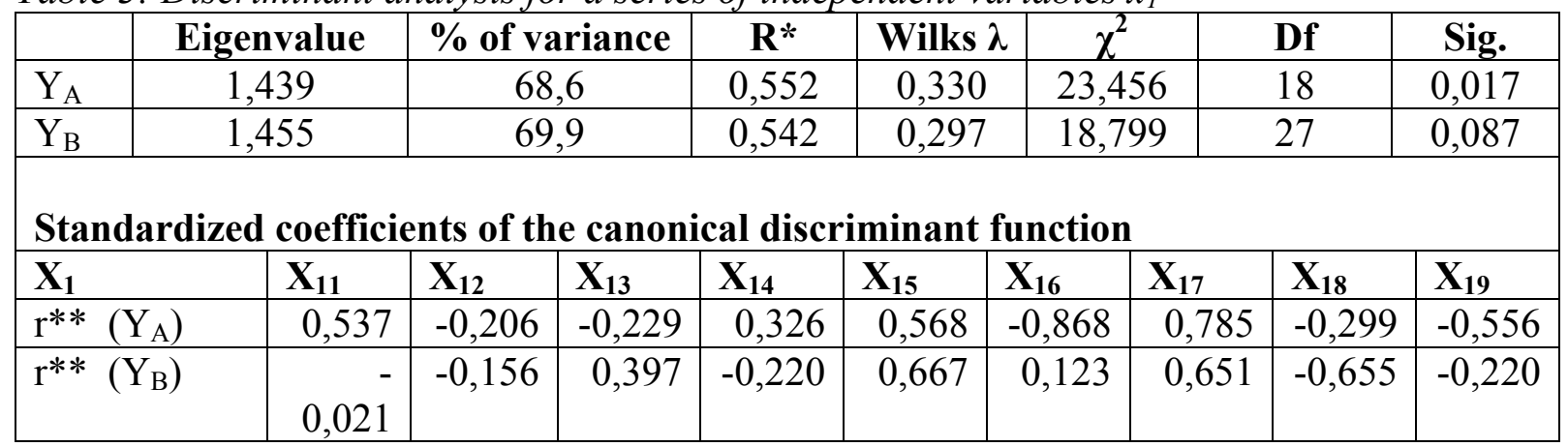


Notes:

* R - canonical correlation coefficient, indicating the strength of correlation between discriminant values and the group of independent variables;

** $\mathrm{r}$ - standardized coefficients of the canonical discriminant function

Because canonical correlation coefficients $(\mathrm{R})$ for both aggregate variables are higher than 0,5 , there exists a correlation between the value of individual factors of attractiveness of a supplier, and the frequency of implementation of purchasing marketing strategies of type A and type B.

The companies which implement purchasing marketing strategies of type A more frequently, have evaluated their strategic supplier higher with regard to the following factors: »supplier's capacity«, »supplier's management« and »delivery in due time«, while the following two factors have been assessed the lowest: »product quality « and »supplier's ability to meet market requirements «.

Therefore, the research hypothesis H1a has been fully supported, because there is no significant negative correlation between weighted value of the majority of factors, with which the companies have measured the attractiveness of existing strategic suppliers, and the frequency of implementation of transactional purchasing marketing strategies.

The companies which implement purchasing marketing strategies of type B more frequently, have evaluated their strategic supplier higher with regard to the following factors: »supplier management« and »delivery in due time«, but the lowest with regard to the $»$ purchasing price $\ll$.

The research hypothesis H1b has not been supported, because there is no significant positive correlation between the weighted value of the majority of factors, with which the companies have measured the attractiveness of existing strategic suppliers, and the frequency of implementation of relationship purchasing marketing strategies.

\section{b) Factors of attractiveness of total purchasing market for a buyer}

Table 4:

Discriminant analysis for a series of independent variables $\mathbf{x}_{2}$

\begin{tabular}{|l|c|c|c|c|c|c|c|}
\hline & Eigenvalue & $\begin{array}{c}\text { \%o of } \\
\text { variance }\end{array}$ & $\mathbf{R}^{*}$ & Wilks $\boldsymbol{\lambda}$ & $\chi^{\mathbf{2}}$ & $\mathbf{D f}$ & Sig. \\
\hline $\mathrm{Y}_{\mathrm{A}}$ & 1,255 & 71,5 & 0,451 & 0,233 & 11,982 & 14 & 0,046 \\
\hline $\mathrm{Y}_{\mathrm{B}}$ & 1,290 & 68,9 & 0,474 & 0,486 & 19,528 & 21 & 0,031 \\
\hline \multicolumn{7}{|c|}{ Standardized coefficients of the canonical discriminant function } \\
\hline $\mathbf{X}_{\mathbf{2}}$ & $\mathbf{X}_{\mathbf{2 1}}$ & $\mathbf{X}_{\mathbf{2 2}}$ & $\mathbf{X}_{\mathbf{2 3}}$ & $\mathbf{X}_{\mathbf{2 4}}$ & $\mathbf{X}_{\mathbf{2 5}}$ & $\mathbf{X}_{\mathbf{2 6}}$ & $\mathbf{X}_{\mathbf{2 7}}$ \\
\hline $\mathrm{r}^{* *}\left(\mathrm{Y}_{\mathrm{A}}\right)$ & 0,151 & 0,102 & $-0,971$ & 0,249 & 0,294 & 0,001 & 0,700 \\
\hline $\mathrm{r}^{* *}\left(\mathrm{Y}_{\mathrm{B}}\right)$ & 0,676 & $-0,235$ & $-0,673$ & 0,421 & $-0,217$ & 0,412 & 0,124 \\
\hline
\end{tabular}

As the canonical correlation coefficients $(\mathrm{R})$ are smaller than 0,5 for aggregate dependent variables $\mathrm{Y}_{\mathrm{A}}$ and $\mathrm{Y}_{\mathrm{B}}$, we can conclude that there is no correlation between the degree of attractiveness of the purchasing market and the frequency of implementation of purchasing marketing strategies of companies. Standardized canonical discriminant function coefficients for the set of dependent variables $Y_{A}$ and for the set of dependent variables $Y_{B}$ are statistically insignificant for the majority of independent variables (i.e. factors of 
attractiveness of the purchasing market for a buyer). Thus, research hypothesis $2 \mathrm{a}$ and $2 \mathrm{~b}$ have not been supported.

Because canonical correlation coefficients $(\mathrm{R})$ for both dependent variables are higher than 0,5 , there exists a correlation between factors of buyer's competitive position on the purchasing market and the frequency of implementation of both types of purchasing marketing strategies.

The companies, which implement purchasing marketing strategies of the type A more frequently, have achieved strong competitive position on the purchasing market, if it has been measured by the following two factors: »the ratio between supply costs and supply value « and »demand price elasticity«. On the other hand, their competitive position is relatively weak if »switching costs« have been taken into consideration.

c) Factors of buyer's competitive position on the purchasing market

Table 5:

Discriminant analysis for a series of independent variables $\mathbf{x}_{3}$

\begin{tabular}{|c|c|c|c|c|c|c|c|c|}
\hline & Eigenvalue & \multicolumn{2}{|c|}{$\begin{array}{c}\% \text { of } \\
\text { variance }\end{array}$} & $\mathbf{R}^{*}$ & Wilks $\lambda$ & $\chi^{2}$ & Df & Sig. \\
\hline $\mathrm{Y}_{\mathrm{A}}$ & 1,313 & 79,6 & & 0,589 & 0,205 & 12,774 & 16 & 0,048 \\
\hline $\mathrm{Y}_{\mathrm{B}}$ & 1,655 & 82,6 & & 0,718 & 0,039 & 33,588 & 24 & 0,020 \\
\hline \multicolumn{9}{|c|}{ Standardized coefficients of the canonical discriminant function } \\
\hline $\mathbf{X}_{3}$ & $\mathbf{X}_{31}$ & $\mathbf{X}_{32}$ & $\mathbf{X}_{33}$ & $\mathbf{X}_{34}$ & $\mathbf{X}_{35}$ & $\mathbf{X}_{36}$ & $\mathbf{X}_{37}$ & $\mathbf{X}_{38}$ \\
\hline $\mathrm{r}^{* *}$ & $-0,053$ & $-0,584$ & 0,771 & & $-0,0$ & 0,185 & $-0,154$ & 0,563 \\
\hline $\mathrm{r}^{* *}$ & $-0,010$ & 0,011 & $-0,203$ & & 0,3 & 0,324 & 0,537 & $-0,622$ \\
\hline
\end{tabular}

* $\mathrm{R}$ - canonical correlation coefficient, indicating the strength of correlation between discriminant values and the group of independent variables;

** $\mathrm{r}$ - standardized coefficients of the canonical discriminant function

The research hypothesis $3 \mathrm{a}$ has been supported because there is a significant positive correlation between the competitive position (i.e. the majority of factors for assessing a buyer's competitive position on the purchasing market), and the frequency of implementation of transactional purchasing marketing strategies.

The companies, which implement purchasing marketing strategies of the type B more frequently, have stronger relative competitive position related to $\gg$ the level of available reliable marketing information" and weaker competitive position related to the factor »price elasticity of demand $\ll$.

The research hypothesis $\mathrm{H} 3 \mathrm{~b}$ has not been supported because there is no significant negative correlation between the competitive position (i.e. the majority of factors for measuring the level of buyer's competitive position on the purchasing market), and the frequency of implementation of relationship purchasing marketing strategies. 
d) Factors for bargaining orientation of a buyer

Table 6:

Discriminant analysis for a series of independent variables $\mathbf{x}_{4}$

\begin{tabular}{|c|c|c|c|c|c|c|c|c|c|}
\hline & \multicolumn{2}{|c|}{ Eigenvalue } & \multicolumn{2}{|c|}{$\%$ of variance } & $\mathbf{R}^{*}$ & Wilks $\lambda$ & \multicolumn{3}{|r|}{ Sig. } \\
\hline $\mathrm{Y}_{\mathrm{A}}$ & & 420 & & 58,0 & 0,54 & 0,267 & 18,036 & 26 & 0,087 \\
\hline $\mathrm{Y}_{\mathrm{B}}$ & & 911 & & 72,8 & 0,73 & 0,037 & 39,603 & 39 & 0,044 \\
\hline \multicolumn{10}{|c|}{ Standardized coefficients of the canonical discriminant function } \\
\hline \multicolumn{2}{|l|}{$\mathbf{X}_{4}$} & \multicolumn{2}{|l|}{$\mathbf{X}_{41}$} & \multicolumn{2}{|l|}{$\mathbf{X}_{42}$} & & & & \\
\hline \multicolumn{2}{|c|}{$\mathrm{r}^{* *}\left(\mathrm{Y}_{\mathrm{A}}\right)$} & & $-0,168$ & \multicolumn{2}{|c|}{$-0,574$} & & & & \\
\hline \multicolumn{2}{|c|}{$\mathrm{r}^{* *}\left(\mathrm{Y}_{\mathrm{B}}\right)$} & & 0,051 & \multicolumn{2}{|c|}{0,360} & & & & \\
\hline \multicolumn{10}{|c|}{$\begin{array}{l}\text { Notes: } \\
* \mathrm{R} \text { - canonical correlation coefficient, indicating the strength of correlation between discriminant values and the group of independent } \\
\text { variables; } \\
\text { ** } \mathrm{r} \text { - standardized coefficients of the canonical discriminant function } \\
\text { Because canonical correlation coefficients (R) for both dependent variables are higher than } 0,5 \text {, there exists a correlation between } \\
\text { factors related to the buyer's bargaining power, and the frequency of implementation of both types of purchasing marketing strategies. } \\
\text { Both standardized canonical discriminant function coefficients of the independent variable } \mathrm{x}_{41} \text {, i.e. "a buyer's orientation toward } \\
\text { risk", are statistically insignificant. } \\
\text { There is statistically significant negative correlation between the buyer's orientation toward cooperation, and the frequency of } \\
\text { implementation of transactional purchasing marketing strategies. Therefore, the research hypothesis 4a has been supported partially, while } \\
\text { the research hypothesis } 4 \mathrm{~b} \text { has not been supported at all. }\end{array}$} \\
\hline
\end{tabular}

\section{FINDINGS, CONTRIBUTIONS AND MANAGERIAL IMPLICATIONS}

\subsection{FINDINGS AND CONTRIBUTIONS}

Globalization and technological innovation of the companies in service industry evidently impact the creation of dynamic and specific networks or chains of interconnected players to bring and deliver more value for the customer (Srivastava, Singh, 2010, 3).

However, results of our empirical research have indicated that the companies in service industry in Slovenia implement the most frequently the purchasing marketing strategies with fast, short-term (immediate), and direct effects on their business performance and purchasing savings (i.e. strategies oriented toward decreasing purchasing costs and costs of production), as well as to ensure safety of purchasing activities and diminish the level of business risks, consequently.

It was also found out that researched companies develop certain strategies with their strategic suppliers, which are characteristic for the concept of »relationship marketing «, nevertheless their prevailing purchasing activities are still oriented toward classical buyersupplier relations, prevailed in »transactional« marketing.

The analysis of the impact of qualitative elements of buyers' B2B relational exchange with their strategic suppliers on the frequency of implementation of purchasing marketing strategies has shown to us some correlations between supplier's attractiveness, buyer's competitive position on the purchasing market, bargaining orientation of a buyer on the one hand, and the frequency of implementation of particular purchasing marketing strategies (transactional and relationship strategies) on the other hand. But, there are no statistically significant correlations between the attractiveness of total purchasing market and dependent variable.

A thorough insight into standardized canonical discriminant function coefficients with regard to individual groups of qualitative factors (groups of independent variables) has revealed the following conclusions:

- the weighted value of individual qualitative factors of relational exchange, as well as the content of these factors for supplier's evaluation, had very different impact on the 
frequency of implementation of both types of purchasing marketing strategies (type $a$ and type $b$ );

- stronger competitive position of a buyer reduces its tendency to implement relationship purchasing marketing strategies (nevertheless the strategic supplier has tried to establish a long-term relationships);

- more intensive buyer's risk orientation toward a supplier does not have direct effects (perhaps there are some indirect effects) on the frequency of implementation of a certain type of purchasing marketing strategy;

- the buyers, which are more intensive oriented towards cooperation, more frequently implement such purchasing marketing strategies which are characteristic for the concept of »relationship marketing «.

The results of this research contribute to the literature in important ways. First, in previous research studies authors did not analyze the linkage between qualitative elements of buyer's relational exchange process with its strategic supplier and the implementation of its purchasing marketing strategies.

Second, this research also contributes to a greater understanding of the factors that influence partner selection and attractiveness of purchasing market as a whole.

Third, we extended the research of qualitative elements of relational exchange of the buyers in service industry in Slovenia on B2B market by demonstrating the behaviour of such companies in the relationship with their strategic suppliers, which indicate a great level of opportunistic behaviour and inconsistent decisions, because there is very significant difference between what does company do on one hand and what does company really want to achieve.

There are a huge number of authors, who have analyzed the buyers' perspectives of buyer-seller relationship development on B2B market (Claycomb, Frankwick, 2010; Mitrega, Katrichis, 2010; King, Burgess, 2008; Palmatier, Scheer, Evans, Arnold, 2008; Duffy, 2008; Grayson, 2007; Hawkins, Wittmann, Beyerlein, 2008 et. al.), but the above mentioned authors and others did not emphasize the role of relationship' characteristics in creating and performing purchasing marketing strategies. It is evidently true that the empirical investigations about the effects of marketing activities from the buyer's perspective on its purchasing B2B market toward their strategic suppliers are handled deficiently in the current literature. Therefore, the following paper represents the significant strategic link between the theory of the relationship on one hand and the strategic purchasing marketing decisionmaking on the other hand.

Last but not least, this research makes a contribution to the strategy literature and to the practitioners, and has important implications for purchasing managers by offering guidelines for mixing the various aspects of partnering according to their objectives and strategies in order to improve the level of their relational approach to their strategic suppliers.

\subsection{Managerial implications}

Our results caution on inconsistency between the level of relational exchange and the strategic purchasing marketing activities of larger companies in service industry in Slovenia. The selected suppliers can be attentive on the marketing behaviour of the buyers, who do not commit to develop the existing relationship with the appropriate marketing strategies. Such situation can decrease a level of trust between the companies and enhance opportunistic behaviour.

Therefore in addition to having realistic expectations for the relationship between a buyer and a supplier, an accurate assessment of the status of a relationship is important for managers looking to develop appropriate interaction strategies (Duffy, 2008, 238). 
Buyers on B2B market in service industry in Slovenia looking to move along the relational continuum regarding the level of quality of the relationship should take note of the importance of trust and relational norms, as its key role in discriminating between all relationship types highlights the importance of ensuring the consistency between the relationship status of the buyer and derived purchasing marketing strategies. Therefore these results imply the managers on both the supply and buy side need to become considerably more discriminating when they decide to join in any supply relational exchange that is considerably more than a discrete purchase. Some suppliers may view such buyer's use of transactional purchasing marketing strategies as opportunistic behaviour when the reality is that they are simply a tool to help a buyer gain the best possible price.

Thus, results of our study have managerial implications for both buyers and suppliers who should recognize that while relationship quality regarding attractiveness of the market, competitive position of its players, and bargaining orientation of both of them on one side, and conflict resolution on the other side are important aspects of buyer-supplier relationships, their use may not always lead to the desired relationship characteristics. For this reason, the cooperative implementation of purchasing marketing strategies as strategic marketing assets contributes to gain competitive advantage as well as sustained profitability of the buyer.

\section{RESEARCH LIMITATIONS AND DIRECTIONS FOR FURTHER RESEARCH}

There are some important research limitations which have to be taken into account during evaluation of the research. First, the sampling error as the result of difference between the characteristics of service companies in the sample and total statistical population of service companies in Slovenia, has some impact on relevance of research results. Second, the effect of qualitative elements of relational exchanges on the frequency of implementation of individual purchasing marketing strategies was researched by empirical model of selected individual independent variables and the empirical model of 25 selected purchasing marketing strategies. Therefore, our model cannot be generalized on all qualitative elements of relational exchanges as well as on all possible purchasing marketing strategies, performed by the companies in B2B relations. Additional research should investigate other key performance drivers in the relation researched. Third, since we aggregated the values of dependent variables to two sub-groups, the results of this study should be viewed with caution. Fourth, the use of multiple discriminant analysis and canonical correlation analysis somehow narrows the possible empirical results. To improve this methodological area the application of structural equation models (SEM) can be appropriate in this context. Fifth, the answers on our questions in the questionnaire have resulted in personal (subjective) perceptions of respondents (CEO's and presidents of companies). Of course, it is not necessary that their perception fit with objective situation in analysed companies.

Our present empirical research has also revealed some elements that marketing scholars should devote considerable attention in their further researches. It is evident that some additional factors during investigating B2B relational exchange from the buyer's point of view should be considered in order to evaluate a creativity of such relationship, i.e. trust, availability of sources of supply, motivational factors, the level of capability (competences) of governing relationship effectively (Wang, Bradford, Xu and Weitz, 2008, 110; Palmatier, Scheer, Evans and Arnold, 2008, 178), perceived effectiveness and efficiency of relationship (Palmatier, Scheer, Evans and Arnold, 2008, 178), uncertainty (Crosno and Dahlstrom, 2008, 192), time (duration), and the experience of the participants in the relational exchange (Fink, James and Hatten, 2008, 375; Laaksonen, Pajunen and Kulmala, 2008, 918).

Usually several members of a buying center in the company of buyer participate in longterm relationships with suppliers as well as in creating and implementing purchasing 
marketing strategies. Therefore, future research could include several members (not only one of them) of the buying center who interact with the supplier in order to receive more relevant information about strategic decisions and plans of the buyer.

\section{REFERENCES:}

Anders, W. (1992). Strategische Einkaufsplannung. Peter Lang, Inc.

Bagozzi, R.P. (1995). Reflections on Relationship Marketing in Conusumer Markets; Journal of the Academy of Marketing Science, 23; pp. 272-277.

Baily P., Farmer, D., Jessop D., Jones D. (1994). Purchasing Principles and Management; Pitman Publishing London.

Batt, P.J., Purchase, S. (2004). Managing Collaboration within Networks and Relationships; Industrial Marketing Management; Vol. 33(3); pp. 169-174.

Beckman, C.M., Haunschild, P.R., Phillips, D.J. (2004). Friends or Strangers? Firm-specific Uncertainty, Market Uncertainty, and Network Partner Selection; Company Science; Vol. 15(3); pp. 259-275.

Bove, L.L., Johnson, L.W. (2001). Customer Relationships with Service Personel: Do we measure Closeness, Quality or Strength; Journal of Business Research; Vol. 54(3); pp. 189197.

Bunduchi, R. (2008). Trust, Power and Transaction Costs in B2B Exchanges - A SocioEconomic Approach; Industrial Marketing Management; Vol. 37(5); pp. 610-622.

Claycomb, C., Frankwick, G.L. (2010). Buyers' perspectives of buyer-seller relationship development; Industrial Marketing Management: 39; pp. 252-263.

Crosno, J.L., Dahlstrom, R. (2008). A Meta-Analytic Review of Opportunism in Exchange Relationships; Journal of the Academy of Marketing Science; Vol. 36(3); pp. 191-201.

De Wulf, K., Odekerken-Schroeder, Iacobucci, D. (2001). Investments in Consumer Relationships: A Cross-Country and Cross-Industry Explorations; Journal of Marketing, 65; pp. 33-50.

Duffy, R.S. (2008). Towards a better understanding of Partnership Attributes: An Exploratory Analysis of Relationship Type Classification; Industrial Marketing Management; Vol. 37(2); pp. 228-244.

Dwyer, F. R., Schurr, P. H., Oh, S. (1987). Developing Buyer - Seller Relationships; Journal of Marketing; Vol. 51(2); pp. 11-27.

Ellram, L.M. (1990). The Supplier selection Decision in Strategic Partnership; Journal of Purchasing and Material Management; Vol. 26(1); pp. 8-14. 
Fink, R.C., James, W.L., Hatten, K.J. (2008). Duration and Relational Choices: Time based Effects of Customer Performance and Environmental Uncertainty on Relational Choice; Industrial Marketing Management; Vol. 37(4); pp. 367-379.

Grayson, K. (2007). Friendship Versus Business in Marketing Relationships; Journal of Marketing; Vol. 71; pp. 121-139.

Groenroos, C. (1994). Quo Vadis, Marketing? Towards a Relationship Marketing Paradigm; Journal of Marketing Management; Vol. 10(1); pp. 12-15.

Gummesson, E. (1995). The New Marketing - Developing Long-Term Interactive Relationships; in McDonald, M., Marketing Strategies; New Approaches, New Techniques; Pergamon; pp. 83-101.

Hald, K.S., Cordon, C., Vollmann, T.E. (2009). Towards an understanding of atraction in buyer-supplier relationships; Industrial Marketing Management Vol. 38(4); pp. 960-970.

Hawkins, T.G., Wittmann, C.M., Beyerlein, M.M. (2008). Antecedents and consequences of opportunism in buyer-supplier relations: Research synthesis and new frontiers; Industrial Marketing Management: 37; pp. 895-909.

Heide, J.B., John, G. (1990). Alliances in Industrial Purchasing: The Determinants of Join Action in Buyer - Supplier Relationships; Journal of Marketing Research; Vol. 27(1); pp. 2436.

Iacobucci, D. (1996). Networks in Marketing; Thousand Oaks, CA: Sage Publications.

Johanson, J., Mattsson, L. (1987). Interorganizational relations in industrial systems: A network approach compared with the transaction-cost approach. International Studies of Management and Organization, 17(1); pp. 34-48.

Johnson, M.D., Selnes, F. (2004). Customer Portfolio Management: Toward a Dynamic Theory of Exchange Relationships. Journal of Marketing; Vol. 68(2); pp. 1-17.

King, S.F., Burgess, T.F. (2008). Understanding success and failure in customer relationship management; Industrial Marketing Management 37; pp. 421-431.

Koppelmann, U. (1993). Beschaffungsmarketing, Springer-Verlag.

Laaksonen, T., Pajunen, K., Kulmala, H.I. (2008). Co-evolution of Trust and Dependence in Customer-Supplier Relationships; Industrial Marketing Management; Vol. 37(8); pp. 910920 .

Lambe, C.J., Speakman, R.E., Hunt, S.D. (2002). Alliance Competence, Resources, and Alliance Success: Conceptualization, Measurement, and Initial Test; Journal of the Academy of Marketing Science; Vol. 30(2); pp. 141-158.

Lancaster, G., Reynolds, P. (1998). Marketing. MacMillan Business Masters. 
Lovelock, C., Wirtz, J. (2011). Services Marketing; People, Technology, Strategy; 7th ed. Pearson Publ.

McKenna, R. (1991). Marketing is Everything; Harvard Business Review, 69; pp. 65-79.

Mesquita, L.F., Anand, J., Brush, T.H. (2008). Comparing the Resource-Based and Relational Views: Knowledge Transfer and Spillover in Vertical Alliances; Strategic Management Journal; Vol. 29(9); pp. 913-941.

Mitrega, M., Katrichis, J.M. (2010). Benefiting from dedication and constraint in buyer-seller relationships; Industrial Marketing Management: 39; pp. 616-624.

Monczka, R., Trent, R., Handfield, R. (2005). Purchasing \& Supply Chain Management; 3rd. ed. Thomson South -Western.

Morgan R.M., Hunt, S.D. (1994). The Commitment-Trust Theory of Relationship Marketing; Journal of Marketing, Vol. 58(1); pp. 20-25.

Nunnally, J.C. (1978). Psyhometric Theory. New York: Mc.Graw-Hill.

Palmatier, R.W., Scheer, L.K., Evans, K.R., Arnold, T.J. (2008). Achieving Relationship Marketing Effectiveness in Business-to-Business Exchanges; Academy of Marketing Science; Vol. 36(2); pp. 174-190.

Palmatier, R.W., Dant, R.P., Grewal, D. (2007). A comparative longitudinal analysis of theoretical perspectives of interorganizational relationship performance; Journal of Marketing, 71; pp. 172-194.

Palmer, A., Mayer, R. (1996). A Conceptual Evaluation of the Multiple Dimensions of Relationship Marketing; Journal of Strategic Marketing; Vol. 4(4); pp. 207-220.

Powell, W.W. (1987). Hybrid organizational arragements: new form or transitional development? California Management Review, 30(1), pp. 67-87.

Ritter, T., Wilkinson, I.F., Johnston, W.J. (2004). Managing in Complex Business Networks; Industrial Marketing Management; Vol. 33(3); pp. 175-183.

Saunders, M. (1997). Strategic Purchasing \& Supply Chain Management; 2nd ed.; Financial Times Prentice Hall.

Shah, R.H., Swaminathan, V. (2008). Factors Influencing Partner Selection in Strategic Alliances: The Moderating Role of Alliance Context; Strategic Management Journal; Vol. 29(5); pp. 471-494.

Siguaw, J.A., Baker, T., Simpson, P. (2003). Preliminary Evidence on the Composition of Relational Exchange and its Outcomes: The Distributor Perspective; Journal of Business Research; Vol. 56(4); pp. 311-322.

Srivastava, V., Singh, T. (2010). Value creation through relationship closeness. Journal of Strategic Marketing; Vol. 18(1); pp. 3-17. 
Qualls, W. J., Puto, C. P. (1989). Companyal Climate and Decision Framming: An Integrated Approach to Analyzing Industrial Buying Decisions; Journal of Marketing Research; Vol. 26(2); pp. 179-192.

Venkatraman, N., Ramanujan, V. (1986). Measurement of business performance in strategy research: A comparison of approaches. Academy of Management Journal, 11; pp. 801-814.

Walter, A., Muller, T.T., Helfert, G., Ritter, T. (2003). Functions of Industrial Supplier Relationships, and their Impact on Relationship Quality; Industrial Marketing Management; Vol. 32(2); pp. 159-169.

Wang, Q., Bradford, K., Xu, J., Weitz, B. (2008). Creativity in Buyer - Seller Relationships: The Role of Governance; International Journal of Research in Marketing; Vol. 25(2); pp. 109-118.

Westbrook, K., W. (1996). Risk Coordinative Maneuvers During Buyer - Seller Negotiations; Industrial Marketing Management; Vol. 25(4); pp. 283-292.

Wuyts, S., Geyskens, I. (2005). The Formation of Buyer - Supplier Relationships; detailed Contract Drafting and Close Partner Selection; Journal of Marketing; Vol. 69(3); pp. 103117.

\title{
KAKO KVALITATIVNI ELEMENTI RAZMJENA ZBOG ODNOSA UTJEČU NA IMPLEMENTACIJU KUPOVNIH MARKETINŠKIH STRATEGIJA - SLUČAJ USLUŽNIH PODUZEĆA U SLOVENIJI
}

\begin{abstract}
Sažetak
Autor istražuje vezu između kvalitativnih elemenata razmjene zbog odnosa i implementacije marketinških strategija baziranih na odnosu nasuprot transakcijskih marketinških strategija iz perspektive kupca u B2B razmjeni (između poslovnih subjekata). Stoga su određene četiri grupe faktora kvalitativne razmjene bazirane na odnosu: privlačnost dobavljača, privlačnost ukupnog nabavnog tržišta za kupca, konkurentnost kupca na nabavnom tržištu te pregovaračka orijentacija kupca prema njegovom strateškom dobavljaču. Baveći se uslužnim poduzećima u usponu s više od 200 zaposlenih u Sloveniji i njihovim odnosom sa strateškim dobavljačem, autor sugerira da kupčeva percepcija kvalitativnih elemenata odnosne razmjene utječe na korištenje određenih marketinških strategija prema strateškom dobavljaču. Rezultati empirijskog istraživanja pokazuju određenu korelaciju između istraženih grupa varijabli. Utjecaj istraženih faktora na implementaciju određene grupe marketinških strategija postoji, iako je najsnažniji utjecj onih faktora koji su karakteristični za kratkoročne odnose. Stoga su istražena poduzeća puno više orijentirana prema ostvarivanju kratkoročne nego dugoročne efikasnosti. Ovo istraživanje doprinosi strateškoj literaturi i profesionalcima u ovom polju te ima važne implikacije za menadžere nabave nudeći smjernice za miješanje raznih aspekata partnerstva u odnosu na ciljeve i strategije kako bi se poboljšala razina njihovog odnosnog pristupa strateškom dobavljaču.
\end{abstract}

Ključne riječi: kvalitativni elementi odnosne razmjene, transakcijski marketing, marketing baziran na odnosu, kupovne marketinške strategije. 